\title{
State Support Measures for the Russian Economy in Connection with Coronavirus Infection
}

\author{
Submitted 06/06/20, 1st revision 16/07/20, 2nd revision 29/08/20, accepted 15/09/20 \\ Dzyuba L.M. ${ }^{1}$, Fedorenko N.V. ${ }^{2}$, Fedorenko Yu.V. ${ }^{3}$, Hegetova S.E. ${ }^{4}$, \\ Korolenko I.I. ${ }^{5}$, Kuzmenko O.V. ${ }^{6}$
}

\begin{abstract}
:
Purpose: Coronavirus infection is the most dangerous disease that quickly spreads across the globe, having a negative impact on the entire life of mankind. The pandemic of this virus has an impact not only on the health of citizens, but also on all spheres of life, limiting all channels of interaction both within states and in the field of international legal relations. In these conditions, the economy is, as it were, put on pause, except for the industries that provide for the vital needs of mankind. Who exactly and how to support in order for the state to survive is the most difficult and complex problem for the entire country? This paper examines the issues of assistance and support from the state to the economic sphere of the life of society in our country, as well as how the pandemic affected not only the economy of the Russian Federation, but also the economy of other countries. Therefore, the purpose of this work is to study the measures of state support for the economy of the Russian Federation in connection with the coronavirus infection.
\end{abstract}

Design/Methodology/Approach: When preparing this article, certain methods were applied, namely descriptive, comparative, and also the method of analysis.

Findings: On the basis of the analyzed material, conclusions are drawn about this situation, unique for modern politics, economy and society

Practical Implications: The comprehensive analysis of the coronavirus pandemic effects on economic sectors could contribute to the development of complex anti-crisis state policy in difficult situations.

\footnotetext{
${ }^{1}$ Candidate of philos. sciences, senior lecturer Rostov State University of Economics, Rostovon-Don, Russian Federation, dzuba017@ mail.ru;

${ }^{2}$ Professor, doctor of social sciences, head. Department of civil procedure, Rostov State

University of Economics, Rostov-on-Don, Russian Federation, fedorenko_vladim@mail.ru;

${ }^{3}$ Candidate of Legal sciences, associate Professor of the Department of civil procedure,

Rostov State University of Economics, Rostov-on-Don, Russian Federation,

yuliafedorenko1708@gmail.com;

${ }^{4}$ Candidate of Legal sciences, associate Professor of the Department of civil procedure, Rostov State University of Economics, Rostov-on-Don, Russian Federation,

kse2562@mail.ru;

${ }_{5}^{5}$ Candidate of Legal sciences, associate Professor of the Department of Civil Procedure of

Legal Procedure, Rostov State University of Economics, Rostov-on-Don, Russian

Federation, korolenko.irina.2013@mail.ru;

${ }^{6}$ Candidate of Legal sciences, associate Professor of the Department of Civil Procedure of

Legal Procedure, Rostov State University of Economics, Rostov-on-Don, Russian

Federation,09@yahoo.com;
} 
Keywords: COVID-19 pandemic, virus, economic measures, government support measures, small and medium-sized businesses.

JEL Code: H10, H12.

Paper type: Research article.

\section{Introduction}

The coronavirus, rapidly spreading across states and continents, has become a global phenomenon, affecting the human existence of all countries, as well as the entire world community. According to the World Health Organization, the number of people infected with COVID-19 worldwide exceeded 16.68 million as of July 29, 2020. The United States of America has become the leader in the number of confirmed cases of infection with a new coronavirus infection. Brazil is in second place, India is in third (RBC, 2020a). According to the stopkoronavirus.rf portal, 828,990 infected people were registered in Russia as of July 29, at the moment our country ranks fourth in the world ranking (SK, 2020). The pandemic has negatively affected all countries of the world (Grima et al., 2020; Khan et al., 2020). And Russia is no exception.

\section{Main Issues}

For 2020 and beyond, the Russian Federation had plans for economic growth of 2 percent or more. The level of growth in the actual disposable income of citizens should have increased by $2.2-2.4 \%$. The average annual exchange rate was supposed to be 63.9 rubles / \$ 1 . The average annual price of the Urals brand for 2020 was supposed to be $\$ 57.7$ per barrel (Finmarket, 2020).

However, everything changed very dramatically. The impact of COVID-19 on the economy of the Russian Federation can be traced in various directions, in various forms, with a different burden of consequences, but it covers all areas of activity, all citizens.

The first thing that was affected by COVID-19 is associated with a decrease in tourist flow from China, which affected the economy of the entertainment industry, air travel, and the costs of non-residents in our country. Further, the export of raw materials to the Republic of China began to decline - both mineral (70 percent of all Russian exports to China) and non-raw materials (food, timber). At the same time, imports from infected countries and stopping organizations also decreased, which had an impact on the trade balance of our country and on the provision of some imported goods from China (TADVISER, 2020). The decrease in demand from the Republic of China for the energy resources of our country has become a factor in the decrease in the level of their production. 
Due to the spread of COVID-19, borders have been closed, international economic ties have ceased, and a production gap has occurred. And international trade at present is trade in high-tech goods. The supply of these goods is the result of the concentration of the forces of the majority of producers from different countries. And the Russian Federation does not stand aside from such processes, although not to the same extent. But most of all, Russia feels the negative consequences in the demand for its natural resources on international markets due to the slowdown in production in the states that import Russian raw materials.

The international economy may receive less than $\$ 2.7$ trillion as a result of COVID19 in 2020, while, according to experts, the Russian Federation may receive less than 4.35 trillion rubles. This is the forecast presented by analysts at Bloomberg Economics. In it, experts presented 4 scenarios for the development of the world economy after the COVID-19 pandemic and gave their analysis of what such scenarios will have on the economic growth of various states. Under 2 scenarios out of 4, a recession will occur in the Russian Federation (Forbes, 2020).

Initially, in accordance with the Decree of the Government of the Russian Federation «On the approval of the list of sectors of the Russian economy most affected by the deterioration of the situation as a result of the spread of a new coronavirus infection» in Russia, nine industries were identified that were most affected by the current economic situation. Subsequently, the list of affected sectors of the economy was replenished several times and now there are twelve of them. In the opinion of the state, these sectors are more in need of assistance from the state than others.

The measures developed included the formation of an anti-crisis fund for 300 billion rubles, tax incentives for the affected sectors of the economy, access to concessional lending, and much more (Consultant, 2020).

The Government of the Russian Federation also proposed to simplify the availability of foreign medicines on the Russian market, to partially abolish benefits for domestic pharmaceutical companies at state auctions, control the cost of food and essential goods, subsidize interest rates on loans to organizations, compensate for the costs and losses of transport and tourism organizations, provide support cultural and sports organizations, to provide leasing organizations with additional capitalization and to postpone the payment of insurance premiums for small and medium-sized businesses for 3 months.

The worst negative impact due to COVID-19 in our country is felt by small businesses that engage in activities in a wide variety of services. The leadership of the Russian Federation understands this and tried to focus their efforts on providing small businesses with the opportunity to survive this crisis and are trying to implement the necessary measures for comprehensive support. 
However, the measures taken by the leadership of the Russian Federation cause a wave of criticism as insufficient.

The non-working period introduced by the President of the Russian Federation (from March 30 to May 11) with the preservation of salaries for all employees of organizations has hit the business of our country hard. In social networks, the statement of the famous designer Artemy Lebedev caused immense popularity, where he indicates that his studio will work in the usual format during the non-working period introduced. «It's very cool that people will keep their wages. And where to get money for it? AND? Maybe the state will compensate private companies for their expenses? Or how? - pointed out Lebedev. «It's very cool that people will keep their wages. And where to get money for it? AND? Maybe the state will compensate private companies for their expenses? Or how? - pointed out Lebedev.

There are an infinite number of people willing to be generous at my expense. But in this case, Vladimir Vladimirovich, we will continue to work as before, because design is not oil, we have no super profits here. And weeks of vacation, even at your request, threaten us with bankruptcy, and we will still be useful to the country. Therefore, I have to refuse you». A number of other large companies followed his example: SuperJob, DNS, Citymobil, Ozon, Rambler Group, Yandex.

As a result of the "half-hearted measures» of the country's leadership, legal uncertainty about the labor obligations of workers appeared. Employees who were transferred to remote work had the right to continue to perform their duties from home, as pointed out by the presidential press secretary Dmitry Peskov. However, such recommendations were not formalized in any regulatory document, and it was not clear to the business whether telecommuting employees should perform their duties during non-working days.

It is worth noting that already in the first week of anti-coronavirus measures in the Russian Federation, the President's secretary himself noted their lack (RBC, 2020b). Representatives of 48 percent of small and medium-sized enterprises in Russia indicated that it was impossible to apply the measures of business support proposed by the country's leadership, since " their enterprise does not fall into the category of organizations that receive assistance» (BBC, 2020). Let us dwell on the most striking measure of support offered by the Government of the Russian Federation and see how it is being implemented in practice.

The most discussed measure to support the leadership of the Russian Federation was interest-free loans to pay salaries to employees. 150 billion rubles were allocated for this support measure.

However, in practice, banks did not actively issue such soft loans. One of the largest banks in Russia, Sberbank, satisfied only one fifth of all applications. 
The situation is complicated by the fact that the list of banks participating in this program is rather limited: interest-free loans can only be issued by those banks whose credit rating is not lower than A-

Small and medium-sized businesses that have been working for at least 1 year and are included in the list of affected sectors of the economy that we mentioned above are eligible for this salary loan.

There is still a question in the ears of acting businessmen in our country: why not help all enterprises? In addition, cash payments for the salaries of their employees are provided not free of charge, but as a loan, which means they will be returned.

\section{Conclusions}

The modern economy has definitely not faced such a global problem. This disease leaves an imprint not only on the economy, but also on the social life of society. People, states, employers are beginning to realize which spheres of activity are really important for society, in which direction it is necessary to carry out structural changes in the future, responding to modern challenges.

The state must learn the «lessons of the crisis» and subsequently significantly revise the tax burden and regulatory requirements during a period of stability in relation to those business segments that, as the crisis showed, collapse literally within a few weeks of downtime.

At the moment, there are many uncertainties in terms of the development of the situation, but it is definitely clear that this is one of the most difficult tests.

\section{References:}

BBC. 2020. Unaffordable Aid: Why Business in Russia Cannot Get Government Support. Available online: https://www.bbc.com/russian/features-52358221

Consultant. 2020. Coronavirus and anti-crisis measures (updated daily). Available online: http://www.consultant.ru/news/58/

Finmarket. 2020. The average annual price of Urals in 2020 will be $\$ 57.7$ per barrel forecast of the Ministry of Economic Development. Available online: http://www.finmarket.ru/news/5163334

Forbes. 2020. A disease costing trillions of rubles: how much will the coronavirus cost for Russia. Available online: https://www.forbes.ru/newsroom/biznes/394551-bolezncenoy-525-trln-rubley-vo-skolko-rossii-oboydetsya-koronavirus

Grima, S., Dalli Gonzi, R., Thalassinos, I.E. 2020. The Impact of COVID-19 on Malta and its Economy and Sustainable Strategies. Available at SSRN: https://ssrn.com/abstract=3644833 or http://dx.doi.org/10.2139/ssrn.3644833.

Khan, S., Rabbani, R.M., Thalassinos, I.E., Atif, M. 2020. Corona Virus Pandemic Paving Ways to Next Generation of Learning and Teaching: Futuristic Cloud Based Educational Model. Available at SSRN: https://ssrn.com/abstract=3669832. 
RBC. 2020a. Coronavirus pandemic. The most relevant data. Available online:

https://www.rbc.ru/society/29/07/2020/5e2fe9459a79479d102bada6

RBC. 2020b. The Kremlin pointed out problems in the support measures proposed by the authorities. Available online: https:

//www.rbc.ru/society/17/04/2020/5e9976dd9a79475b2fb79df2

SK. 2020. Operational data of the Russian COVID-19 web-portal. Available online: https: //xn--80aesfpebagmfblc0a.xn--p1ai/

TADVISER. 2020. The impact of the coronavirus COVID-19 on the economies of the countries of the world. Available online:

https://www.tadviser.ru/index.php/\%D0\%A1\%D1\%82\%D0\%B0\% D1\% 82\% D1\% 8C\% D1\% 8F:\% D0\% 92\% D0\% BB\% D0\% B8\% D1\% 8F\% D0\% BD\% D0\% B8\%

D0\% B5_\% D0\% BA\% D0\% BE\% D1 \% 80\% D0\% BE\% D0\% BD\% D0\% B0\% D 